\title{
Research using cells derived from fertilised human ovum: can this be morally justified?
}

The recent passing of the Embryology Bill has important implications for research that might lead to major advances in therapy, but raises moral issues which make many people doubt whether such an approach is justified. I know that religion plays an important part in Charles's life but also that he is capable of standing back and looking at moral issues as objectively as possible. So I raised the matter with him.

'What's your view on the use of fertilised human embryos in medical research?'

'There is no easy answer', Charles replied, 'but I would rather talk about "fertilised ova" than "human embryos". There are at least two questions: "Is there a morally acceptable way of obtaining cells derived from the fertilised ovum" and "Is one ever justified in using the cells if there is?"

\section{‘Go on,' I said.}

'Let's start at the very beginning. As you know, I have sympathy with what might be regarded as oldfashioned moral views and therefore am unhappy about some of the methods of obtaining the fertilised ovum. I will put that entirely aside as I don't think they are fundamental to the argument.'

'Fair enough.'

Charles continued, 'It seems to me that if killing is wrong then taking a human life at any stage is wrong. To my mind this is not influenced by events which are external to the individual such as birth and quickening, let alone an arbitrary time in gestation, whether or not based on some concept of liability after birth. I therefore have every sympathy with those people who believe there is no fundamental difference in killing a human being at any stage of development once it is recognisable as an individual in theological terms. This means once it has a human spirit or soul.'

'But don't many churches regard conception as the moment that the soul enters the body?'

'Yes,' he said, 'but is a fertilised ovum a recognisable single human individual? What happens in the course of the early stages of development?'
'The cells divide and multiply, first as a little blob of cells and then the yolk sac, and the head and tail ends become established.'

'Is it possible to say which point on the surface of the fertilised ovum will become the head?'

'As I understand it, no. Indeed this does not happen for a few divisions and before that time, every cell can become anything or everything.'

'I thought that might be so. This line of thought developed when I asked myself the question: "When do identical twins get their individual souls?" Is this predetermined? Does God give two souls to the ovum at the time of fertilisation?'

'I know that one does not necessarily have to regard God as in the same space time continuum as oneself, but that seems a little artificial to me.'

'Yes, I agree', he said. 'To me it is more attractive that twins get their souls as the fertilised ovum and its subsequent bundle of cells are clearly split into two. If that is so, might the human soul or spirit enter the body of a singleton fetus at the time of its orientation?'

'You feel that could be the defining moment?'

'Yes', he replied, 'apart from fertilisation, the only possible defining moment.'

'So the question is: "Does one destroy a human being if one destroys a fertilised ovum?" I added. 'What's the answer?'

'I don't know', he replied, 'but our discussion might suggest that the use of a fertilised ovum is not necessarily incompatible with a very strict view on abortion. Furthermore if it were possible take one of the first two, four or eight cells and allow the embryo to develop, then this question does not arise, but one still has to ask the second.'

'That is: "Can one use stem cells at all?"' I interjected.

'Yes', he replied. 'Is there not a continuum between the truly pleuri-potential early embryo stem cells, 
adult stem cells and fully differentiated cells. Therefore, if you regard any human tissue culture as moral, I can see no fundamental difference between using stem cells whatever their stage and fully differentiated ones.'

'So, if you can get stem cells in a morally acceptable way, you may use them?'

'I would have thought so' he replied cautiously.
Clearly Charles is strongly influenced by what might now be regarded as old-fashioned moral values but nevertheless did suggest an alternative time when the human soul and spirit might enter the embryo and when the right to life starts. It would be interesting to have a theological view.

Coemgenus 